\title{
PERANCANGAN SISTEM INFORMASI PENILAIAN PRESTASI SISWA PADA SDN GROGOL SELATAN 13
}

\author{
${ }^{1}$ Rouly Doharma, ${ }^{2}$ Dian Mafiroh \\ 1,2) Pogram Studi Sistem Informasi \\ STMIK Widuri Jakarta \\ Email :1rouly.doharma@gmail.com, 마figoh14@gmail.com
}

\begin{abstract}
ABSTRAKSI
Penulisan ini membahas Analisa dan Perancangan Sistem Informasi Penilaian Prestasi Siswa Pada SDN Grogol Selatan 13. Hasil penilaian prestasi siswa dilakukan untuk melakukan evaluasi terhadap ketuntasan belajar peserta didik dan efektivitas proses pembelajaran di sekolah. Penelitian ini menggunakan metode pengumpulan data berupa survey yaitu dengan melakukan wawancara,studi Literatur dan melakukan penelitian terlebih dahulu yang kemudian dipadukan dengan model pembangunan sistem (waterfall). SDN Grogol Selatan 13 memerlukan suatu perancangan dan pembuatan dengan sistem berbasis web dikarenakan pada saat ini proses penilaian prestasi siswa masih secara manual dan tersimpan dalam file yang terpisah sehingga proses pengolahan nilai tidak efektif dan efisien. Dengan adanya rancangan ini diharapkan dapat membantu dalam meningkatkan efektifitas dari proses pendataan penilaian prestasi peserta didik di sekolah dan dapat membantu pendidik dalam proses pengolahan data penilaian peserta didik. Penulis coba membuat suatu sistem pengolahan nilai dengan PHP MySQL
\end{abstract}

Kata kunci : Sistem Informasi, Penilaian Prestasi Siswa Di Sekolah Dasar, PHP, XAMPP. 


\section{PENDAHULUAN}

\subsection{Latar Belakang}

SDN grogol selatan 13 merupakan lembaga pendidikan yang berada di Kecamatan Kebayoran lama. SDN Grogol Selatan 13 masih mengacu kepada kurikulum KTSP 2006. Kurikulum, pembelajaran, dan penilaian merupakan komponen penting dalam kegiatan pembelajaran. Penilaian adalah suatu proses pengumpulan dan pengolahan informasi untuk mengukur hasil pencapaian hasil belajar peserta didik

Kualitas pembelajaran dalam dipengaruhi oleh dua hal yang sama pentingnya yaitu proses dan hasil belajar. Proses belajar berkaitan dengan siswa dalam mempelajari bahan pelajaran, sedangkan hasil berkaitan dengan perubahan perilaku yang diperoleh sebagai pengaruh dari proses belajar. Hasil belajar merupakan salah satu faktor yang dapat menentukan proses belajar. Dengan kata lain, bagaimana seharusnya siswa belajar, akan sangat ditentukan oleh apa hasil yang ingin di peroleh oleh siswa.

Pendapat Anitah (2014:2.6) hakikat belajar merupakan proses belajar harus dapat dilakukan dengan efektif agar dapat menghasilkan penambahan ilmu pengetahuan dan perubahan perilaku siswa. Anitah (2014:2.20) perkembangan siswa SD usia 6-12 tahun yang termasuk pada perkembangan masa pertengahan memiliki fase-fese yang unik dalam perkembangannya yang menggambarkan peristiwa penting bagi siswa yang bersangkutan. Tahapan ini dapat dilihat dari perkembangan (1) fisik, (2) sosial, (3) bahasa, (4) kognitif, (5) moral, (6) ekspresif, (7) aspek intelegensi, (8) aspek kebutuhan siswa.

Penilaian data nilai siswa-siswi SDN Grogol Selatan 13 belum sepenuhnya terkomputerisasi, adapun proses yang dilakukan adalah menerima berkas penilaian siswa-siswi dari setiap guru mata pelajaran setelah itu dicatat dalam buku kumpulan nilai/leger dan menyalinnya kembali kedalam satu buku yang biasa kita kenal dengan Raport. Setelah penyalianan tersebut, raport disimpan kemudian dibagikan kepada siswa/ siswi setelah melakukan UTS (Ulangan tengah Semester ) dan UAS ( Ulangan Akhir Sekolah ).

Pada saat raport berada di siswa-siswi, tidak semua siswa menjaga raport tersebut dengan baik. Masih ada juga beberapa siswa yang tidak perduli, lalai dan ceroboh. Berdasarkan hal tersebut, penulis mengambil judul tentang," Analisa dan Perancangan Sistem Informasi Penilaian Prestasi Siswa Pada SDN Grogol Selatan 13". Sehingga penulis mengambil judul diatas.

\section{LANDASAN TEORI}

\subsection{Konsep Dasar Sistem Informasi \\ 2.1.1 Definisi Sistem}

Menurut Tata Sutabri, Analisa sistem informasi (2003:10), "Sistem adalah setiap kumpulan dari komponen atau sub-sistem yang berinteraksi untuk mencapai suatu tujuan tertentu".

Mendefinisikan sistem secara umum sebagai kumpulan dari elemen-elemen yang berinteraksi untuk mencapai suatu tujuan tertentu sebagai satu kesatuan. (Agus Mulyanto, 2009:1)

Menurut Tata Sutabri (2012:2) terdapat dua kelompok pendekatan di dalam pendefinisian sistem, yaitu kelompok yang menekankan pada prosedur dan kelompok yang menekankan pada elemen atau komponennya. Pendekatan yang menekankan pada prosedur mendefinisikan sistem sebagai suatu jaringan kerja prosedur-prosedur yang saling berhubungan, berkumpul bersama-sama untuk melakukan suatu kegiatan atau untuk menyelesaikan suatu sasaran tertentu.

\subsubsection{Karakteristik Sistem}

Karakteristik sistem adalah sistem yang mempunyai komponen-komponen, batas sistem, lingkungan sistem, suatu penghubung, masukan sistem, keluaran sistem, pengolah dan sasaran.

Berikut adalah karakteristik sistem yang dapat membedakan suatu sistem dengan sistem lainnya yaitu mempunyai komponen - komponen (component), batasan sistem (boundary), lingkungan luar sistem (environment), penghubung (interface), masukan (input), keluaran (output), dan penyimpanan (storage).

\subsubsection{Klasifikasi Sistem}

Menurut Tata Sutabri (2012 : 15) Sistem merupakan suatu bentuk integrasi antara satu komponen dengan komponen lain karena sistem memiliki sasaran yang berbeda untuk setiap kasus yang terjadi di dalam sistem tersebut. Oleh karena itu sistem dapat diklasifikasikan dari beberapa sudut pandangan, seperti contoh sistem yang bersifat abstrak, sistem alamiah, sistem yang bersifat deterministik, dan sistem yang bersifat terbuka dan tertutup.

\subsection{Konsep Dasar Informasi \\ 2.2.1 Definisi Data}

Menurut McLeod dalam bukunya Yakub (Yakub,2012: 5)“ Data adalah deskripsi kenyataan yang menggambarkan adanya suatu kejadian (event), data terdiri dari fakta (fact) dan angka yang secara relatif tidak berarti bagi pemakai". Data dapat berbentuk nilai yang terformat, teks, citra, audio, dan video.

Menurut The Liang Gie dalam Tata Sutabri (2012:2), bahwa data adalah hal, peristiwa, atau kenyataan lain apapun yang mengandung sesuatu pengetahuan untuk 
dijadikan dasar guna penyusunan keterangan, pembuatan kesimpulan, atau penetapan keputusan.

\subsubsection{Definisi Informasi}

Informasi ibarat darah yang mengalir di dalam tubuh manusia, maksud dari kalimat tersebut yaitu bahwa informasi sangat penting pada suatu organisasi. Informasi (information) dapat didefinisikan sebagai berikut:

1. Menurut Mustakini (2009:36), 'Informasi adalah data yang diolah menjadi bentuk yang berguna bagi pemakainya".

2. Menurut McLeod dalam Yakub (2012:8), "Informasi adalah data yang diolah menjadi bentuk yang lebih berguna bagi penerimanya".

\subsubsection{Kualitas Informasi}

Kualitas informasi sangat dipengaruhi atau ditentukan oleh tiga hal pokok, yaitu akurasi (accuracy), relevansi (relevancy), dan tepat waktu (timeliness). (Agus Mulyanto, 2009 : 247).

\subsubsection{Nilai Informasi}

Parameter untuk mengukur nilai sebuah informasi (value of information) ditentukan dari dua hal pokok yaitu manfaat (benefit) dan biaya (cost). Namun, dalam kenyataannya informasi yang biaya untuk mendapatkannya tinggi belum tentu memiliki manfaat yang tinggi pula. Suatu informasi dikatakan bernilai bila manfaatnya lebih efektif dibandingkan dengan biaya untuk mendapatkannya dan sebagian besar informasi tidak dapat tepat ditaksir keuntungannya dengan satuan nilai uang, tetapi dapat ditaksir nilai efektivitasnya.(Agus Mulyanto, 2009 : 247).

\subsection{Konsep Dasar Sistem Informasi \\ 2.3.1 Definisi Sistem Informasi}

Menurut Mulyanto (2009:29), "sistem informasi adalah sebuah komponen yang terdiri dari manusia, teknologi informasi dan prosedur kerja yang memproses, menyimpan, menganalisa dan menyebarkan informasi untuk mencapai suatu tujuan tertentu".

Dari pendapat yang dikemukanan diatas dapat disimpulkan bahwa informasi merupakan gabungan dari orang, hardware, software, jaringan komunikasi, sumber daya data dan kebijakan dan prosedur yang menyimpan , mengumpulkan (mendapatkan kembali),memproses dan mendistribusikan informasi untuk mendukung pengambilan dan pengontrolan keputusan dalam suatu organisasi.

\subsubsection{Komponen Sistem Informasi}

1. Perangkat keras (hardware) yaitu mencakup peranti- peranti fisik komputer dan printer.

2. Perangkat Lunak (software) atau program yaitu sekumpulan instruksi yang memungkinkan peranmgkat keras untuk dapat memproses data.

3. Prosedur yaitu sekumpulan aturan yang dipakai untuk mewujudkan pemprosesan data dan pembangkitan keluaran yang dikehendaki.
4. Orang / Manusia yaitu semua pihak yang bertanggung jawab dalam pengembangan system informasi, pemprosesan, dan penggunaaan keluaran system informasi.

5. Basis data (database) yaitu sekumpulan table, hubungan, dan lain-lain yang berkaitan dengan penyimpanan data.

6. Jaringan computer dan Komunikasi data yaitu system penghubung yang memungkinkan sesumber (resources) dipakai secara bersama atau diakses oleh sejumlah pemakai.

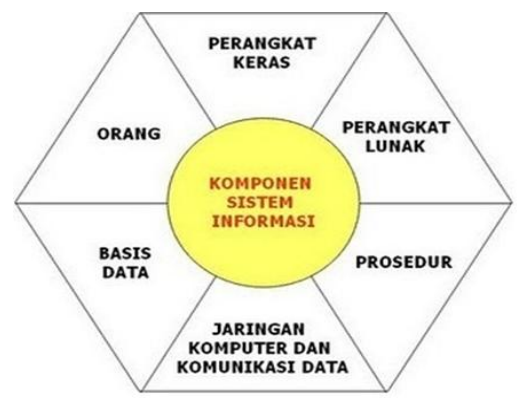

Gambar 1. Komponen Sistem Informasi

\subsection{Sistem Basis Data}

\subsubsection{Pengertian Basis Data}

Menurut Fathansyah (2012: 2) mengemukakan bahwa "basis data terdiri dari 2 kata, yaitu basis dan data. Basis kurang lebih dapat diartikan sebagai markas atau gudang, tempat bersarang / berkumpul. Sedangkan data adalah representasi fakta dunia nyata yang mewakili suatu objek seperti manusia (pegawai, siswa, pembeli, pelanggan), barang, hewan, peristiwa, konsep, keadaan dan sebagainya yang berwujud dalam bentuk angka, huruf, teks, symbol, gambar, bunyi, atau kombinasinya.

\subsubsection{Pengertian Sistem Basis Data}

Sistem basis data merupakan sistem yang terdiri atas kumpulan tabel data yang yang saling berhubungan (dalam sebuah basis data yang disebuah sistem komputer) dan sekumpulan program (yang biasa disebut DBMS / Data Base Maragement System) yang memungkinkan beberapa pemakai dan program lain untuk mengakses dan memanipulasi tabel-tabel data tersebut.

\section{ANALISA SISTEM}

\subsection{Proses Bisnis}

Berikut adalah proses bisnis yang terdapat pada Sistem Informasi Penilaian Prestasi Siswa pada SDN Grogol Selatan 13, antara lain :

1. Proses Pelaksanaan Penilaian prestasi siswa

2. Proses penilaian siswa

3. Proses Pengolahan nilai

4. Laporan 


\subsubsection{Dekomposisi fungsi}

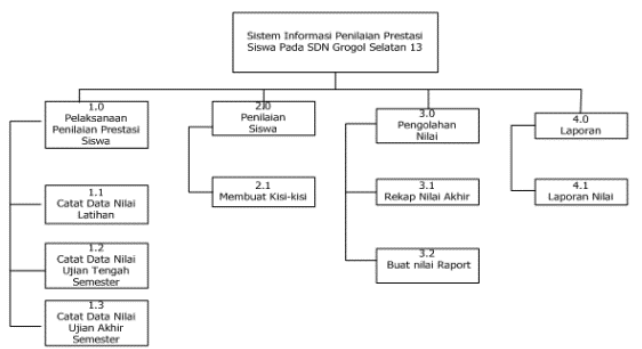

Gambar 2. Dekomposisi Fungsi pada SdN Grogol Selatan 13

\subsubsection{Diagram Konteks}

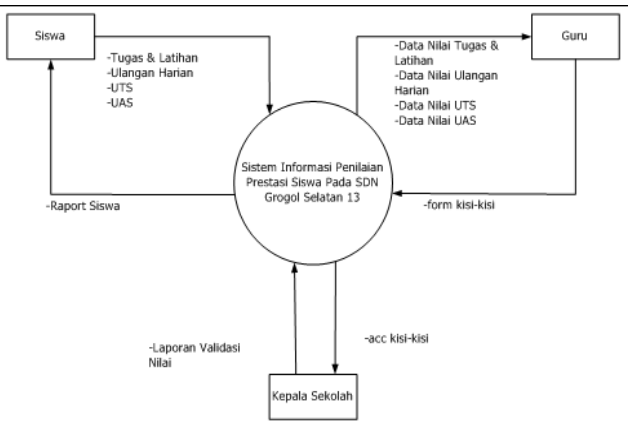

Gambar 3. Diagram Konteks Sistem Informasi penilaian prestasi siswa pada SdN Grogol Selatan 13

\subsubsection{Diagram Overview}

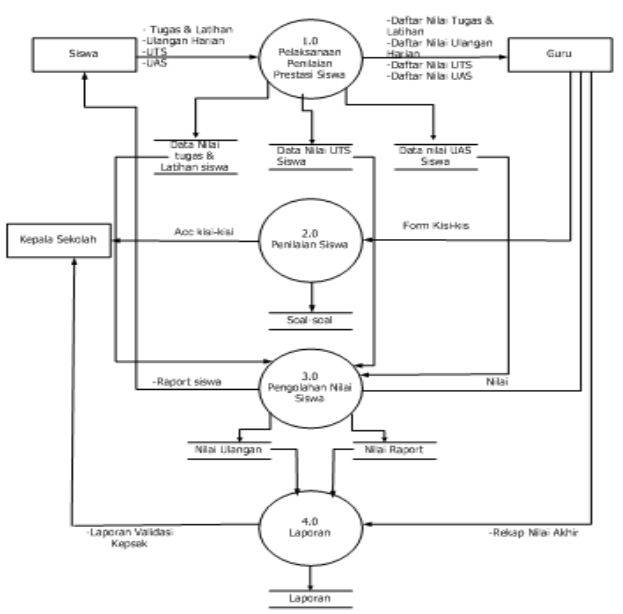

Gambar 4. Diagram Overview Sistem Informasi penilaian prestasi siswa
3.1.4 Diagram Rinci Proses 1.0

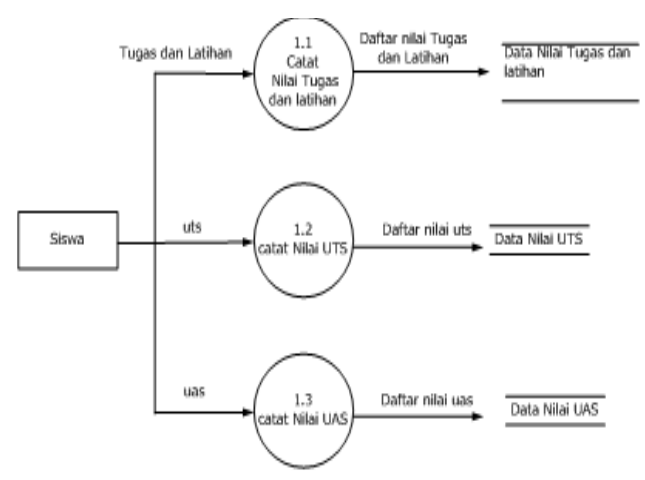

Gambar 5. Diagram Rinci Proses 1

\subsubsection{Diagram Rinci Proses 2.0}

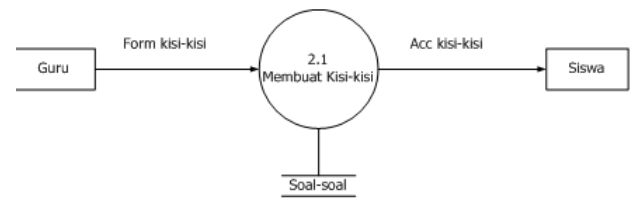

Gambar 6. Diagram Rinci Proses 2

\subsubsection{Diagram Rinci Proses 3}

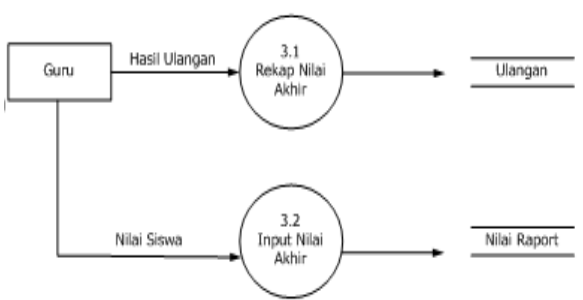

Gambar 7. Diagram Rinci proses 3

\subsubsection{Diagram Rinci Proses 4}

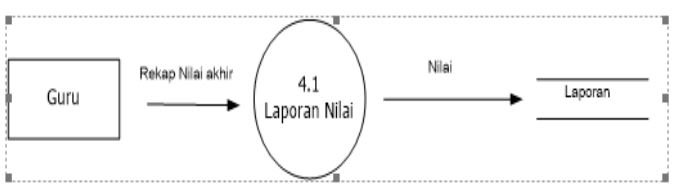

Gambar 8 Diagram Rinci Proses 4 
4. RANCANGAN SISTEM

4.1 Rancangan Proses

4.1.1 Diagram Aliran Data (DAD)

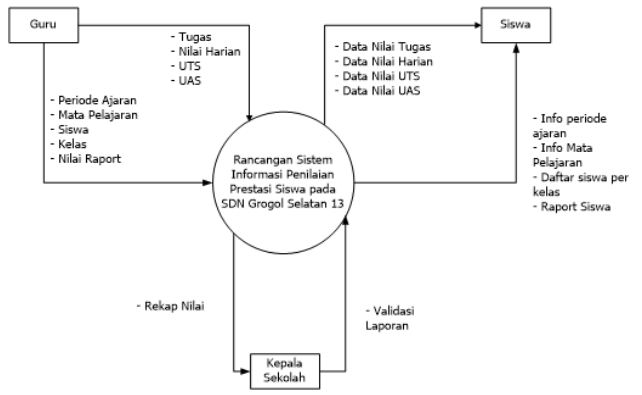

Gambar 9. Rancangan Diagram Konteks Analisa dan Perancangan Sistem Informasi Penilaian Prestasi Siswa Pada Sdn Grogol Selatan 13

\subsubsection{Diagram Overview}

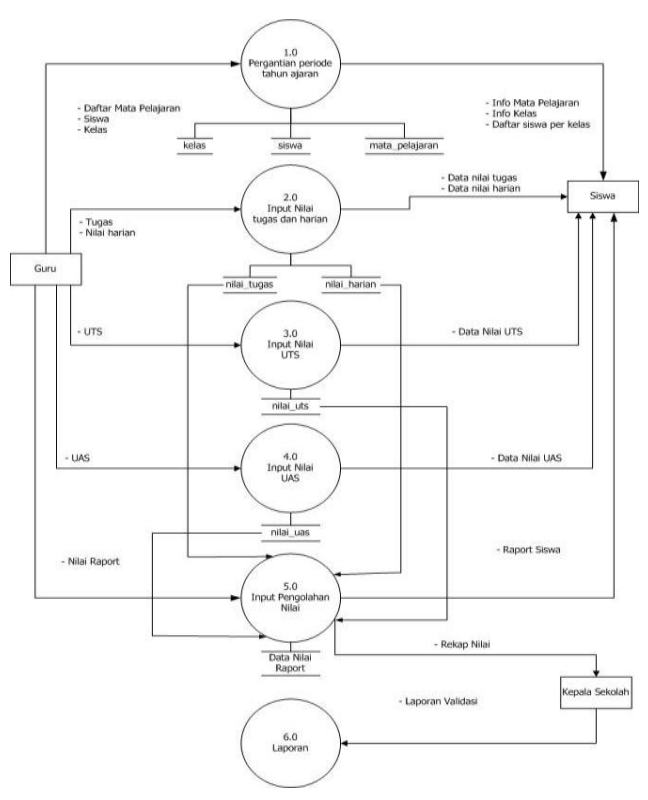

Gambar 10. Rancangan Diagram Overview Analisa dan Perancangan Sistem Informasi penilaian prestasi siswa pada SDN Grogol Selatan 13

\subsubsection{Diagram Rinci Proses 1.0}

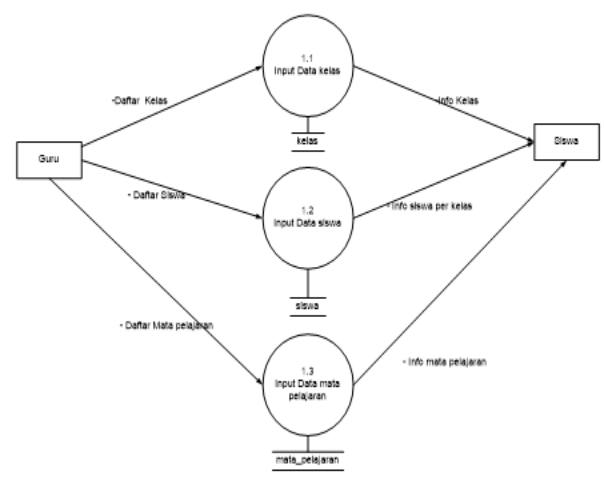

Gambar 11. Diagram Rinci 1.0 Usulan 1.

\subsubsection{Diagram Rinci Proses 2.0}

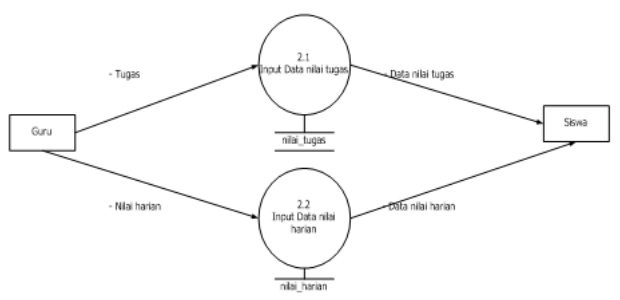

Gambar 12. Diagram Rinci 2.0 Usulan 2.1

\subsubsection{Diagram Rinci Proses 3.0}

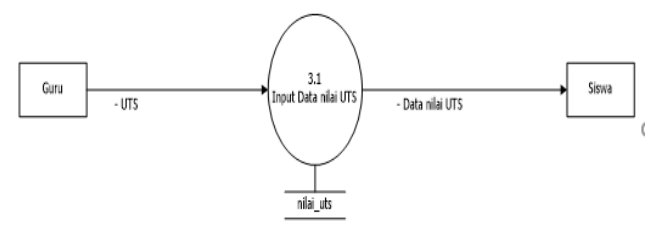

Gambar 13. Diagram Rinci 3.0 Usulan 3.1

\subsubsection{Diagram Rinci Proses 4.0}

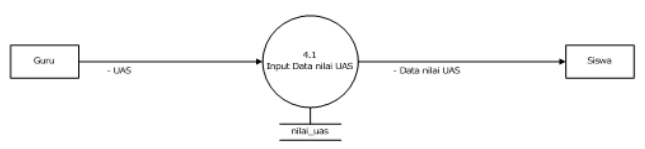

Gambar 14. Diagram Rinci 4.0 Usulan 4.1

\subsubsection{Diagram Rinci Proses 5.0}

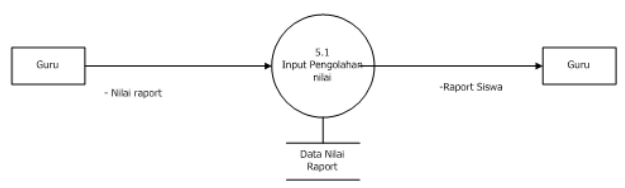

Gambar 15. Diagram Rinci 5.0 Usulan 5.1

\subsubsection{Diagram Rinci Proses 6.0}

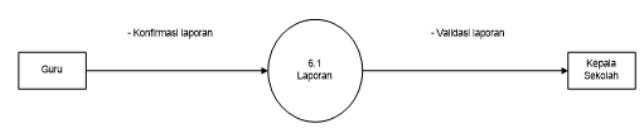

Gambar 16. Diagram Rinci 6.0 Usulan 6.1 


\subsubsection{ERD (Entity Relationship Diagram) Yang}

\section{Diusulkan}

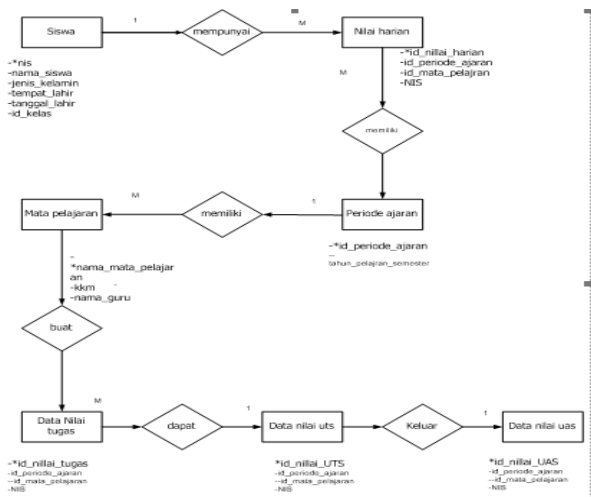

Gambar 17. ERD yang diusulkan pada SDN Grogol Selatan 13

\subsubsection{TRANSFORMASI ERD KE LRS}

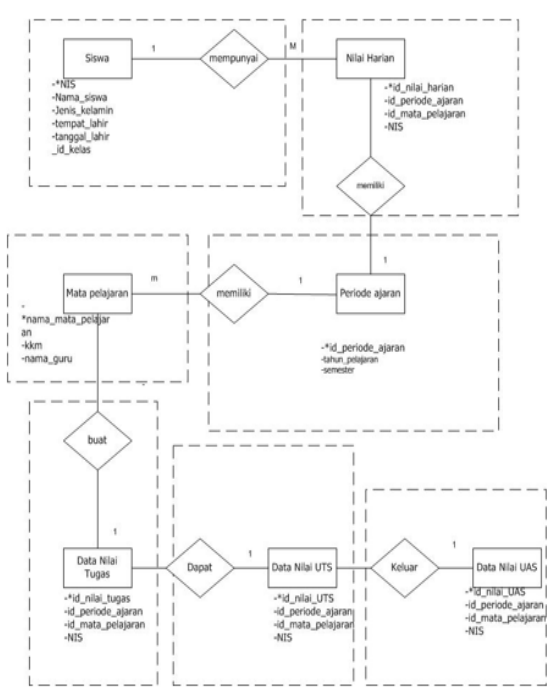

Gambar 18. Transformasi ERD ke LRS

\subsubsection{LOGICAL RECORD STUCTURE (LRS)}

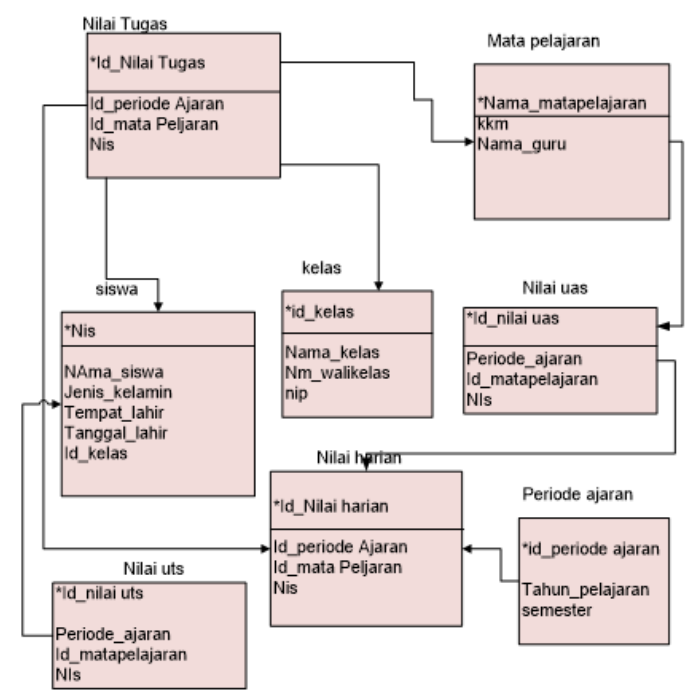

Gambar 19. LRS Usulan Pada SDN Grogol Selatan 13

4.2 Rancangan Dialog Layar

4.3.1 Struktur menu

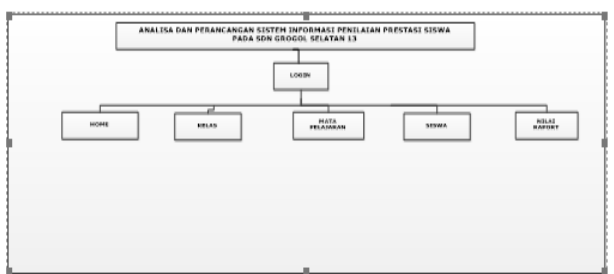

Gambar 20. Struktur menu

\subsubsection{Menu LOGIN}

SELAMAT DATANG SISTEM INFORMASI PENILAIAN PRESTASI

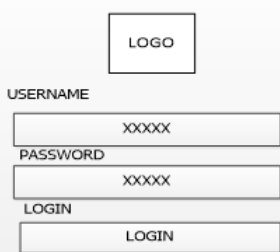

Gambar 21. Tampilan Login Siswa

\subsubsection{Tampilan Layar Home}

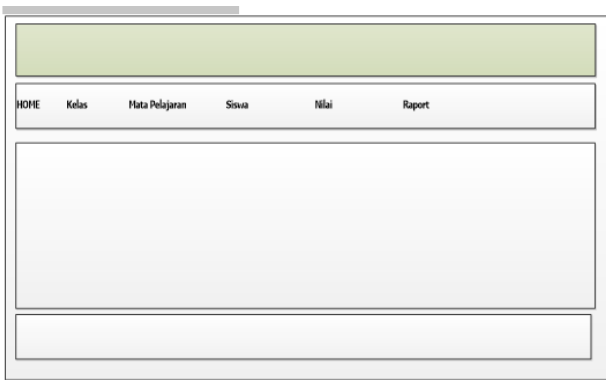

Gambar 22. Tampilan Layar Home

\subsubsection{Menu Kelas}

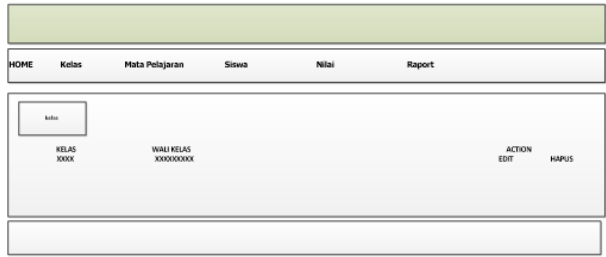

Gambar 23. Tampilan Menu Kelas 


\subsubsection{Rancangan Penginputan Nilai}

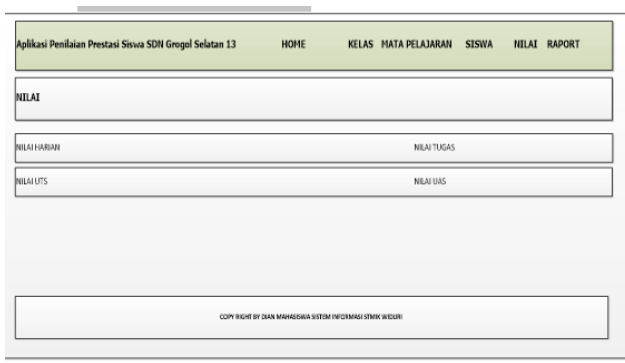

Gambar 24. Penginputan Nilai

\subsubsection{Rancangan Layar Halaman ADMIN Halaman}

Nilai

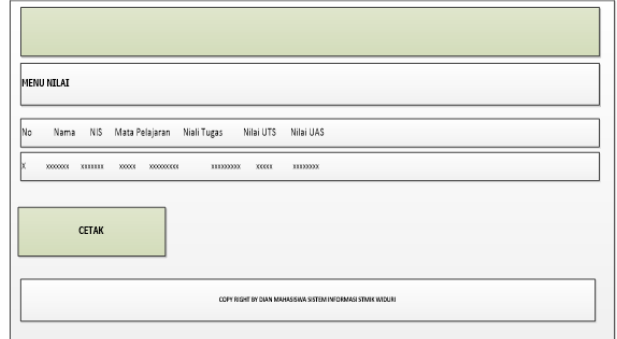

Gambar 25. Rancangan Layar Halaman Admin

\subsection{Pengujian Program}

\subsubsection{Pegujian Black Box Pada Login}

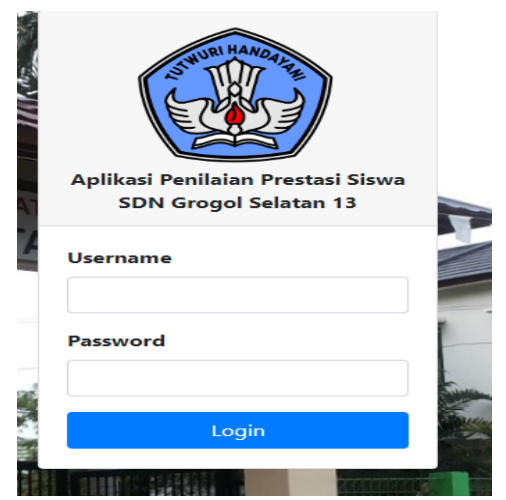

Gambar 26. Tampilan menu login

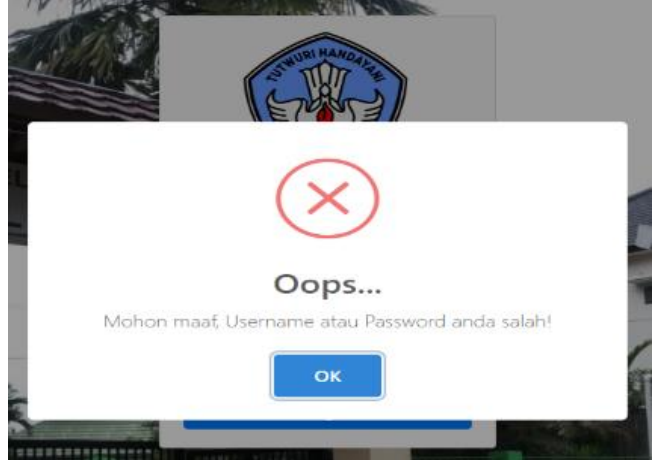

Gambar 27. Tampilan Pesan Tiket untuk login(apabila salah memasukan password)

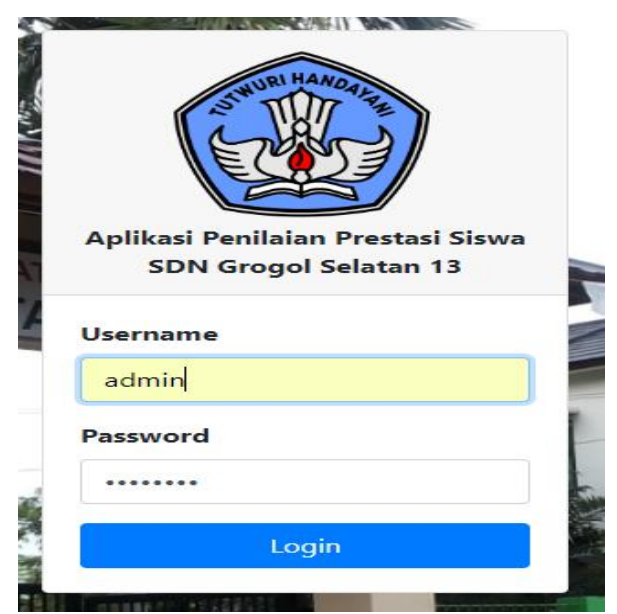

Gambar 28 : Tampilan menu login setelah terisi username dan password

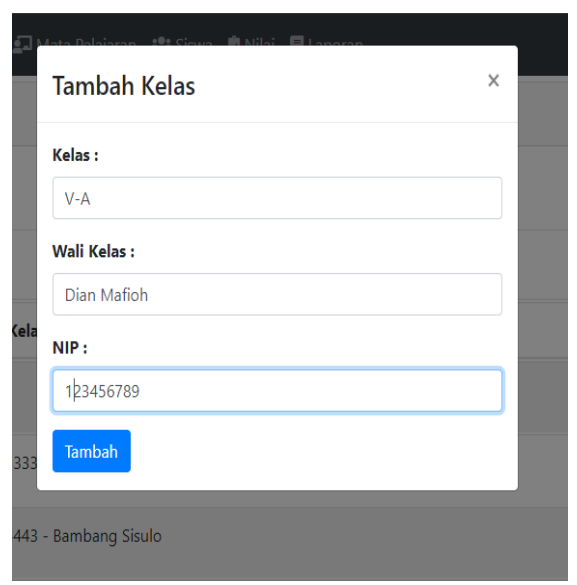

Gambar 29. Tampilan menu home setelah login 


\subsubsection{Tampilan Black Box pada Menu Kelas}

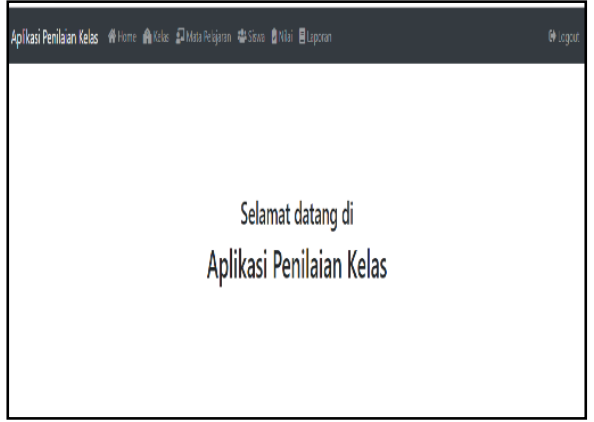

Gambar 30. Tampilan menu Tambah Kelas

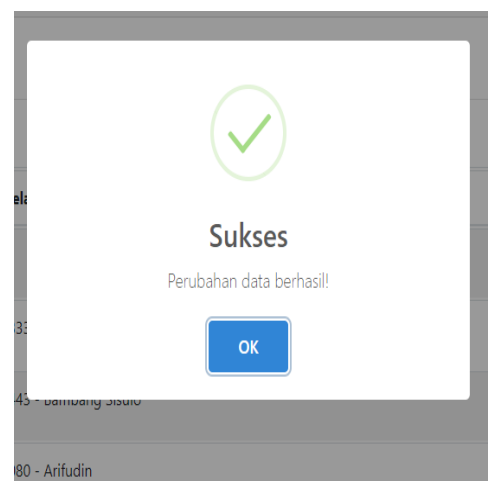

Gambar 31. Tampilan setelah penyimpanan tambah kelas

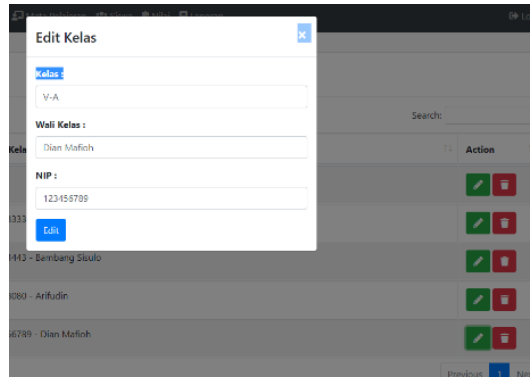

Gambar 32. Tampilan Edit Kelas

\subsubsection{Pengujian Black Box Pada Data Mata} Pelajaran

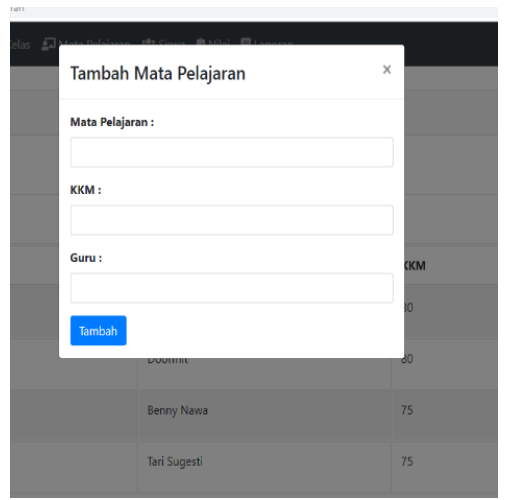

Gambar 33. Tampilan Tambah Mata Pelajaran

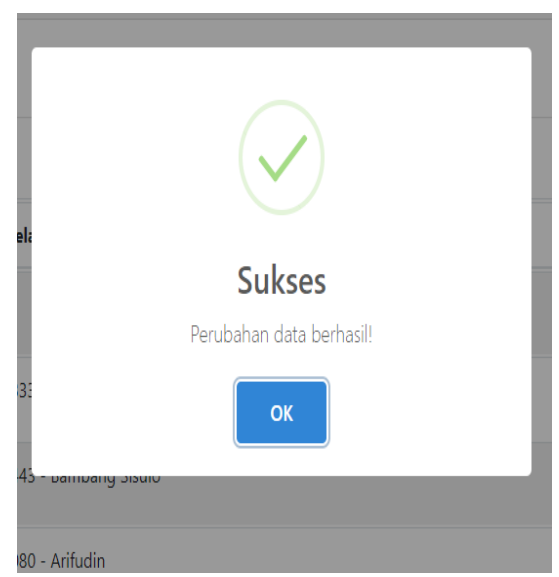

Gambar 34. Tampilan Setelah tambah Mata Pelajaran

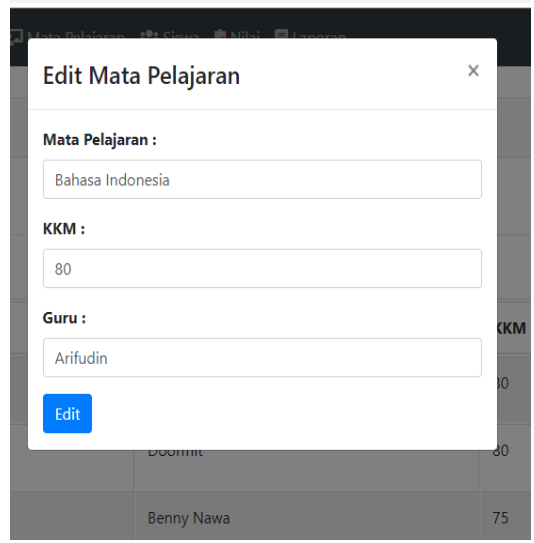

Gambar 35. Tampilan Edit Mata Pelajaran

\subsubsection{Pengujian Black Box Pada Menu Nilai}

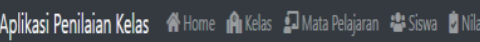

Nilai

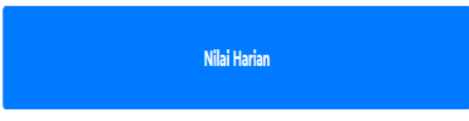

Nilai UTS

Gambar 36. Tampilan menu Nilai Harian 


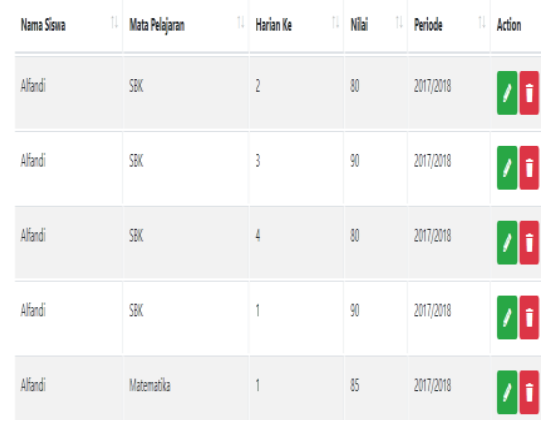

Gambar 37. tampilan view menu nilai

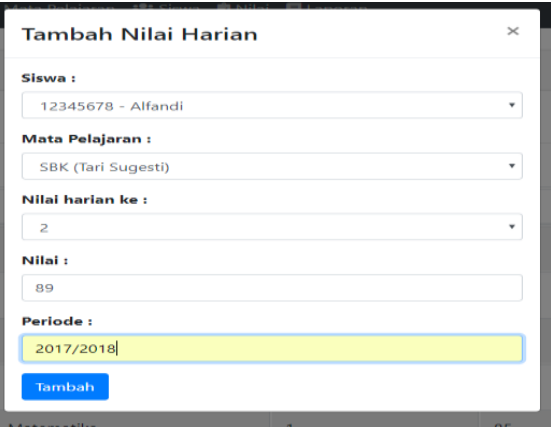

Gambar 38. Tampilan Tambah Nilai Harian

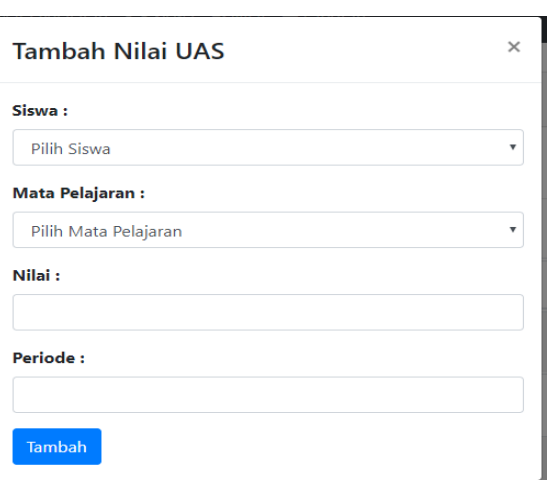

Gambar 41. Tampilan Tambah Nilai UAS

\section{KESIMPULAN DAN SARAN}

\subsection{Kesimpulan}

Dari uraian yang telah penulis paparkan, maka penulis dapat mengambil kesimpulan, beberapa permasalahan yang ada pada sistem lama seperti:

1. Sistem informasi penilaian prestasi siswa pada SDN Grogol Selatan 13 masih menggunakan semi komputer seperti Microsoft exel.

2. Penyampaian informasi yang lama untuk mengetahui up date nilai siswa/siswi.

3. Penanganan dokumen untuk proses hasil belajar yang masih kurang efektif karena prosesnya masih manual dan memakan waktu yang cukup lama.

4. Dalam penginputan datanya, membutuhkan 2 kali proses penyimpanan, yaitu : Penulisan data

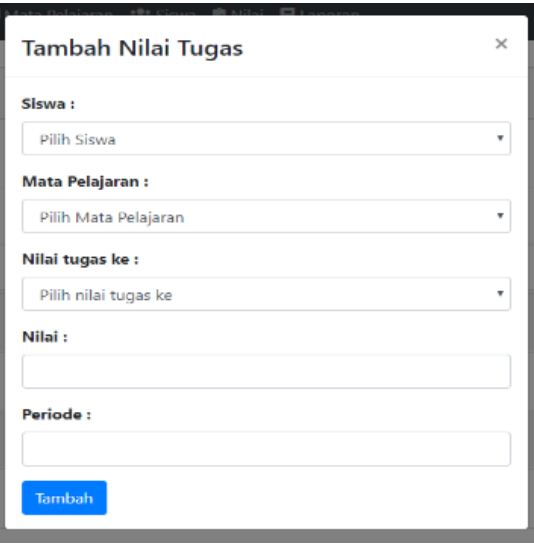

Gambar 39. Tampilan Tambah Nilai Tugas

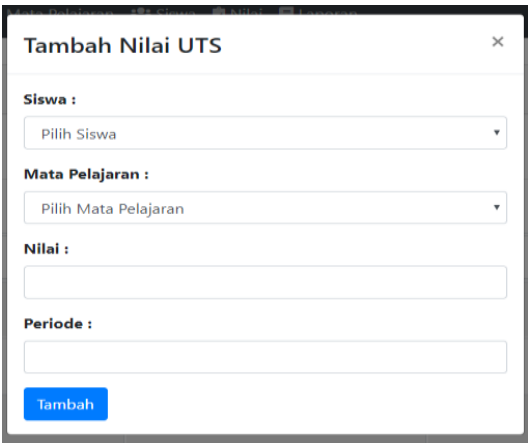

Gambar 40. Tampilan Tambah Nilai UTS

hasil belajar ke buku legger nilai dan data di input kembali ke Microsoft Excel sesuai nama siswa.

\subsection{Saran}

Dengan adanya penelitian pada proposal skripsi ini yang berjudul "ANALISA DAN PERANCANGAN SISTEM INFORMASI PENILAIAN PRESTASI SISWA PADA SDN GROGOL SELATAN 13“, serta rancangan yang di usulkan maka penulis mencoba untuk memberikan saran-saran, antara lain :

1. Meningkatkan pengetahuan dan keterampilan guru dengan cara memfasilitasi pelatihanpelatihan ataupun sejenisnya seperti : In House Training (IHT), pelatihan model-model pembelajaran ataupun metode sebagainya.

2. Pembaharuan aplikasi yang bersifat efisien dan user friendly

3. Untuk aplikasi yang disarankan dalam pembuatannya nanti menggunakan PHP pada bahasa pemprogramannya dan MySQL pada databasenya 


\section{DAFTAR PUSTAKA}

Anitah W, S. (2014). Strategi Pembelajaran di SD. Banten:Universitas Terbuka.

Edi, I. S., \& Sudaryatno, B. (2014). Sistem Informasi Penilaian Siswa Pada Sdn 2 Biting Purwantoro Wonogiri. Data Manajemen dan Teknologi Informasi (DASI), 15(2),1.Link: https://ojs.amikom.ac.id/index.php/dasi/article/vie wFile/186/171, 11 Agustus 2018

Fathansyah. (2012). Basis Data, Bandung: Informatika Indrajani. (2011). Perancangan Basis Data All in 1, Jakarta: Alex Media Komputindo

Juhriah, e. (2015). Perancangan sistem informasi hasil penilaian siswa di smp negeri 96 jakarta berbasis web. Faktor exacta, 7(4), 335-347. Link:http://journal.lppmunindra.ac.id/index.php/F aktor_Exacta/article/view/288,11 Agustus 2018

Kadir, Abdul. (2010). Konsep dan Tuntunan Praktis Basis Data. Yogyakarta: Penerbit Andi.
Mulyanto, Agus (2009), Sistem Informasi \& Aplikasi. Yogyakarta: Pustaka Pelajar

Mustakini, Jogiyanto Hartono. (2009). Sistem Informasi Teknologi. Yogyakarta, Andi Offset

Sutabri, Tata. (2005). Konsep Sistem Informasi. Yogyakarta: Penerbit Andi.

Setiawan, T. B. (2017). Sistem Informasi Pengolahan Data Nilai Siswa Sekolah Menengah Kejuruan (SMK) PGRI 2 Salatiga Berbasis Web Menggunakan Framework Codeigniter(Doctoral dissertation, Program Studi Teknik Informatika FTI-UKSW).

Link:http://repository.uksw.edu/bitstream/123456 789/13532/1/T1_672012047_Full\%20text.pdf, 11 Agustus 2018

Yakub. (2008). Sistem Basis Data; Tutorial Konseptual. Yogyakarta: Edisi Pertama Graha Ilmu. 